\title{
THE ANALYSIS OF TRANSPARENCY OF LISTED COMPANIES IN YEARS 2013-2018
}

\author{
Małgorzata IDASIAK ${ }^{*}$, Dariusz WIELGÓRKA ${ }^{2}$ \\ ${ }^{1}$ Faculty of Management, Częstochowa University of Technology, Częstochowa; gosik15@mail.com, \\ ORCID: 0000-0001-7349-7941 \\ ${ }^{2}$ Faculty of Management, Częstochowa University of Technology, Częstochowa; dariusz.wielgórka@wz.pcz.pl, \\ ORCID: 0000-0001-8241-5688 \\ * Correspondence author
}

Purpose: The objective of the article is to indicate the degree and correctness of the implementation of guidelines in the field of publication of non-financial data.

Design/methodology/approach: The publication has been based on the technique of desk research of a wide selection of domestic and foreign pieces of literature, the analysis of secondary data, the analysis of the content of the press releases and official documents of selected economic entities.

Findings: As a result of the conducted research, the attributes of the entities obliged to publish non-financial data have been identified and the environmental factors, the factors of social responsibility and corporate governance, affecting the effectiveness of the way of informing the capital market, have been indicated. This has become the basis for the presentation of the dynamics of changes in terms of publishing non-financial information by the companies listed on WSE over the last six years.

Research limitations/implications: It is assumed that the indicated legal changes (Directive 2014/95/EU) have contributed to an increase in transparency of the companies listed on the Warsaw Stock Exchange.

Originality/value: The article presents the latest data on the degree of implementation of legal regulations regarding the disclosure of non-financial information by some large entities and groups.

Keywords: ethics, ESG criteria, enterprise, corporate social responsibility.

Category of the paper: General review.

\section{Introduction}

The changing legal conditions concerning the need for disclosure of non-financial data and information relating to diversity by some large entities and groups have led to re-discussing the opportunity to combine ethics and organization management. Directive 2014/95/EU (Directive 
2014/95/EU...) of the European Parliament and of the Council of 22 October 2014 changing Directive 2013/34/EU clearly indicates that the implementation of Corporate Social Responsibility, for many large entities, is no longer a voluntary opportunity to operate and it becomes an obligation ${ }^{1}$.

Due to the fact that in Poland the aspect of disclosure of non-financial data is a new and still not fully understood issue, there is a need to discuss this problem. It is assumed that legal changes resulting from Directive 2014/95/EU and the amendment to the Accounting Act of 29 September 1994 (The Act of 29 September 1994...) contribute to an increase in transparency of the companies listed on the Warsaw Stock Exchange (WSE) (Chudzicki, Wielgórka, 2018, pp. 4-8).

The publication has been based on the technique of desk research of a wide selection of domestic and foreign pieces of literature, the analysis of secondary data and the analysis of the content of the press releases and official documents of selected economic entities.

\section{The content of non-financial reports}

In accordance with the presented legal regulations, the entities obliged to disclose nonfinancial data have certain freedom in reporting them. Entities can freely decide on selecting a standard or guidelines ${ }^{2}$ according to which the report is compiled, however, it must take into account the indicated minimum areas [Journal of Laws of 2017, item 61, art. 49b, section 8].

The indicated areas of reporting non-financial information should include [Journal of Laws 2017, item 61, art. 49b, section 2]:

- description of the unit business model $^{3}$;

- non-financial key performance indicators;

\footnotetext{
${ }^{1}$ In 2001, in the opinion of EU bodies, the concept of CSR was the concept ".... whereby companies integrate social and environmental concerns in their business operations and in their interaction with their stakeholders on a voluntary basis". In 2011, due to changes in the indicated definition, the actions were taken to withdraw from the voluntary phenomenon of CSR - "Corporate social responsibility is the responsibility of enterprises for their impact on the environment".

${ }^{2}$ The guidelines for reporting non-financial data, among others, are: Account Ability 1000, London Institute of Social and Ethical AccountAbility, http://www.mpit.gov.pl/media/15752/Standard_AA1000 Zasady Odpowiedzialnosci_2008.pdf, 22.03.2019, Social Accountability 8000, http://www.mpit.gov.pl/media/15751/ pracodawcy_rp_norma_sa_8000.pdf, 22.03.2019, The Prince's Accounting for Sustainability (A4S), https://www.accountingforsustainability.org/en/index.html, 23.03.2019), ISO 26000, http://www.mpit.gov.pl/ media/42609/discovering_iso_26000.pdf, 22.03.2019, Global Reporting Initiative (GRI), http://www.mpit.gov.pl/media/21611/G4RSPD_Zasadyraportowaniaiwskazniki.pdf, 25.03.2019, ISO 14001, more: L.M.C.M. Da Fonseca (2015), ISO 14001:2015: An Improved Tool for Sustainability, Journal of Industrial Engineering and Management, 8(1). The aspect of the guidelines is more extensively discussed by K.D. Kopeć (2014), Instrumentarium Spolecznej Odpowiedzialności Biznesu, Zarządzanie, Zeszyty Naukowe Politechniki Częstochowskiej, No. 14, pp. 108-110.

${ }^{3}$ The need to indicate the business model in the context of accounting is more extensively interpreted by J. Chluska (2017), Wpływ obowiqzku ujawnień modelu biznesu na system rachunkowości przedsiębiorstw, Kwartalnik Nauk o Przedsiębiorstwie, 11, Vol. 44, No. 3, pp. 94-100.
} 
- description of the policy in terms of social, labour and environmental issues ${ }^{4}$, human rights and anti-corruption;

- description of the procedure of due diligence;

- description of significant risks resulting from the activity of the unit, having impact on the aforementioned areas.

The recommended standard of data reporting, among others, relating to diversity is the NIS standard (Non-Financial Information Standard) ${ }^{5}$ which has been developed on the basis of Directive 2014/95/EU.

The obligatory areas of non-financial data are also often perceived through the prism of three ESG factors (Przychodzen et al., 2016, pp. 2-6):

E - respect for the natural Environment,

$\mathrm{S}-$ Social responsibility $^{6}$,

$\mathrm{G}$ - corporate Governance.

In accordance with the legislation, the entities obliged to disclose non-financial data can publish the indicated information by making:

- a Statement - constituting an integral part of the activity report;

- a Report $^{7}$ - a separate (from the activity report) document containing non-financial data.

The selection of the form of providing capital market information, among others, related to diversity is voluntary. The indicated diversity does not affect the volume of data - both the statement and the report must contain the same elements specified in the Act [Journal of Laws of 2017 , item 61 , art. 49b].

\footnotetext{
${ }^{4}$ In the subject literature referred to as a silent stakeholder.

${ }^{5}$ More information on NIS (SIN), developed by Fundacja Standardów Raportowania and Stowarzyszenie Emitentów Giełdowych, can be found on the official website of SIN, https://standardy.org.pl/wppsndrd/wpcontent/uploads/2017/10/SIN.pdf, (accessed on: 25.03.2019).

${ }^{6}$ The aspect of corporate social responsibility is more extensively discussed by, among others, A.B. Caroll (2008), A History of Corporate Social Responsibility: Concepts and Practices, Business and Management, Business Policy and Strategy, History, January, pp. 20-42; M.E. Porter, M. R.Kramer (2006), Strategy and Society. The link between competitive advantage and corporate social responsibility, Harvard Business Review, December, pp. 78-92; F. Bylok (2017), Podejście etyczne do pracowników w perspektywie społecznej odpowiedzialności przedsiebiorstw, [in:] Zarzadzanie kapitatem ludzkim i spolecznym wobec zmian we wspótczesnych organizacjach, Robak E., Karczewska A., Skiba M (eds.), Wydawnictwo Wydziału Zarządzania Politechniki Częstochowskiej, Częstochowa, p. 47; K. Olejniczak (2012), Spoleczna odpowiedzialność a kreowanie przewagi konkurencyjnej przedsiębiorstw, Sekcja Wydawnictw Wydziału Zarządzania Politechniki Częstochowskiej, Częstochowa.

${ }^{7}$ The volume of the non-financial report may affect a significant increase in the volume of the activity report, therefore it seems reasonable (in the case of an extensive report) to include non-financial information in a separate document.
} 


\section{Dynamics of changes in non-financial data published in years 2013-2018}

The analysis of changes in publishing non-financial data includes the companies listed on a regulated market on the Warsaw Stock Exchange, belonging to the WIG20, WIG40, sWIG80 indices. The companies were subjected to the analysis in accordance with the indicated ESG criteria. In each of the specified categories the entities had to fulfil certain criteria (both general and sectoral). The companies were assessed according to the methodology of $\mathrm{SEG}^{8}$ (Table 1).

Table 1.

Methodology of a company assessment according to SEG

\begin{tabular}{|c|l|}
\hline $\begin{array}{c}\text { Assessment of } \\
\text { the condition }\end{array}$ & Description of the assessment \\
\hline c & No information \\
\hline c + & Tips on the existence of the strategy \\
\hline b- & Extensive policy of the entity \\
\hline b & Policy + program or policy + management system \\
\hline b+ & Policy + program + management system \\
\hline a- & Assessment of progress \\
\hline a & Mechanism for external verification \\
\hline
\end{tabular}

Adapted from: Analiza ESG spótek w Polsce, Raportowanie niefinansowe: Wymagania ustawy o rachunkowości a praktyka rynkowa, Warszawa 2017, p. 17, https://seg.org.pl/sites/seg13.messageasp.com/files/seg_esg-2017_210x297_www-6_1.pdf (accessed on: 28.03.2019).

The degree of disclosure of information on the current and predicted impact of the company activity $^{9}$ on the natural environment (among others, including the use of renewable energy sources, greenhouse gas emissions, water consumption or air emissions) over years 2013-2018 is presented in Table 2 .

Table 2.

The percentage of the companies broken down by the obtained general assessment related to environmental management

\begin{tabular}{|c|c|c|c|c|c|c|}
\hline & $\mathbf{2 0 1 3}$ & $\mathbf{2 0 1 4}$ & $\mathbf{2 0 1 5}$ & $\mathbf{2 0 1 6}$ & $\mathbf{2 0 1 7}$ & $\mathbf{2 0 1 8}$ \\
\hline c & $82.2 \%$ & $81.2 \%$ & $35.6 \%$ & $66 \%$ & $54.3 \%$ & $51 \%$ \\
\hline c + & $12.7 \%$ & $13.5 \%$ & $38.4 \%$ & $21.5 \%$ & $17.9 \%$ & $19 \%$ \\
\hline b- & $3.2 \%$ & $3 \%$ & $12.5 \%$ & $5.9 \%$ & $14.3 \%$ & $14 \%$ \\
\hline b & $1.7 \%$ & $2.4 \%$ & $13.2 \%$ & $6 \%$ & $12.9 \%$ & $14 \%$ \\
\hline b+ & $0.2 \%$ & $0.2 \%$ & $0 \%$ & $0,6 \%$ & $0.7 \%$ & $2 \%$ \\
\hline a- & $0 \%$ & $0 \%$ & $0 \%$ & $0 \%$ & $0 \%$ & $0 \%$ \\
\hline a & $0 \%$ & $0 \%$ & $0 \%$ & $0 \%$ & $0 \%$ & $0 \%$ \\
\hline
\end{tabular}

Own study based on: Analiza ESG spółek w Polsce, 2013, 2014, 2015, 2016, 2017, 2018, own study includes the reports published in 2019.

\footnotetext{
8 See more: Stowarzyszenie Emitentów Giełdowych (The Polish Association of Listed Companies), https://seg.org.pl/pl, 02.04.2019.

${ }^{9}$ The research included 865 companies in 2013, 897 companies in 2014, 143 companies in 2015, 483 companies in 2016,140 companies in 2017, and 100 companies in 2018 .
} 
The presented data indicate that in the analysed years none of the companies (including the WIG20, WIG40 and sWIG80 indices) has disclosed enough information on respect for the environment. The rating of $\mathrm{b}+$ (indicating the existence of both the policy, program and management system taking into account respect for the environment in the business management strategy) was the highest in this part of the analysis. A slight increase in the publication of comprehensive programs and systems of environmental management has been observed since 2016.

The last period of the analysis, taking into account the need for non-financial reporting, illustrates an increase in respect for the biosphere by the companies included in the research.

Table 3.

The percentage of the companies broken down by the obtained general assessment related to social responsibility

\begin{tabular}{|c|c|c|c|c|c|c|}
\hline & $\mathbf{2 0 1 3}$ & $\mathbf{2 0 1 4}$ & $\mathbf{2 0 1 5}$ & $\mathbf{2 0 1 6}$ & $\mathbf{2 0 1 7}$ & $\mathbf{2 0 1 8}$ \\
\hline c & $91.7 \%$ & $88.3 \%$ & $56.6 \%$ & $73.3 \%$ & $49.3 \%$ & $43 \%$ \\
\hline c & $5.3 \%$ & $8.1 \%$ & $24.4 \%$ & $16 \%$ & $20.7 \%$ & $39 \%$ \\
\hline b- & $2.4 \%$ & $2.3 \%$ & $13.9 \%$ & $6.6 \%$ & $9.3 \%$ & $49 \%$ \\
\hline b & $0.5 \%$ & $1 \%$ & $4.8 \%$ & $3.5 \%$ & $10.7 \%$ & $6 \%$ \\
\hline b+ & $0.2 \%$ & $0.2 \%$ & $0.2 \%$ & $0.6 \%$ & $5.7 \%$ & $7 \%$ \\
\hline a- & $0 \%$ & $0 \%$ & $0 \%$ & $0 \%$ & $4.3 \%$ & $5 \%$ \\
\hline a & $0 \%$ & $0 \%$ & $0 \%$ & $0 \%$ & $0 \%$ & $0 \%$ \\
\hline
\end{tabular}

Own study based on: Analiza ESG spółek w Polsce, 2013, 2014, 2015, 2016, 2017, 2018, own study including the reports published in 2019.

The level of reporting information concerning, among others, actions taken in order to ensure gender equality, respect for the rights of internal stakeholders, OHS and respect for stakeholders is presented in Table 3.

Data reporting related to social responsibility has been clarified since 2017. In this period for the first time $4.3 \%$ of the analysed companies recorded significant progress in the field of activities for the benefit of the community.

The attitude of the analysed companies to the publication of data concerning corporate governance is presented in Table 4.

Table 4.

The percentage of the companies broken down by the obtained general assessment related to corporate governance

\begin{tabular}{|c|c|c|c|c|c|c|}
\hline & $\mathbf{2 0 1 3}$ & $\mathbf{2 0 1 4}$ & $\mathbf{2 0 1 5}$ & $\mathbf{2 0 1 6}$ & $\mathbf{2 0 1 7}$ & $\mathbf{2 0 1 8}$ \\
\hline c & $0.8 \%$ & $0.3 \%$ & $0 \%$ & $1.9 \%$ & $63.6 \%$ & $0 \%$ \\
\hline c+ & $2 \%$ & $2.2 \%$ & $0.6 \%$ & $0.8 \%$ & $2.1 \%$ & $24 \%$ \\
\hline b- & $18.8 \%$ & $17.1 \%$ & $3.4 \%$ & $3.3 \%$ & $7.9 \%$ & $9 \%$ \\
\hline b & $52.9 \%$ & $53.4 \%$ & $39.1 \%$ & $41.8 \%$ & $15.7 \%$ & $22 \%$ \\
\hline b+ & $22.1 \%$ & $23.1 \%$ & $46.1 \%$ & $43.9 \%$ & $1.4 \%$ & $30 \%$ \\
\hline a- & $3.3 \%$ & $3.6 \%$ & $10.4 \%$ & $8.1 \%$ & $8.6 \%$ & $11 \%$ \\
\hline a & $0.1 \%$ & $0 \%$ & $0 \%$ & $0.2 \%$ & $0.7 \%$ & $4 \%$ \\
\hline
\end{tabular}

Own study based on: Analiza ESG spółek w Polsce, 2013, 2014, 2015, 2016, 2017, 2018, own study including the reports published in 2019. 
A slight increase in data reporting related to corporate governance of the companies belonging to the WIG20, WIG40 and sWIG80 indices has been observed since 2016. As much as $4 \%$ of the analysed companies obtained the positive assessment, supported by the external verification of actions in the last analysed period. More than half of the entities also indicate having at least a policy or management system in the context of corporate governance.

\section{Table 5.}

The change in the average rating of ESG criteria in the selected sectors of the economy in years 2013-2018

\begin{tabular}{|c|c|c|c|c|c|c|}
\hline Market sector & $\mathbf{2 0 1 3}$ & $\mathbf{2 0 1 4}$ & $\mathbf{2 0 1 5}$ & $\mathbf{2 0 1 6}$ & $\mathbf{2 0 1 7}$ & $\mathbf{2 0 1 8}$ \\
\hline Energy sector & $\mathrm{b} / \mathrm{b} / \mathrm{c}$ & $\mathrm{b}-/ \mathrm{b}-/ \mathrm{b}-$ & $\mathrm{b}-/ \mathrm{b}-/ \mathrm{a}-$ & $\mathrm{b}-/ \mathrm{b}-/ \mathrm{b}+$ & $\mathrm{b} / \mathrm{b}+/ \mathrm{a}-$ & $\mathrm{b} / \mathrm{b} / \mathrm{a}-$ \\
\hline Financial sector & $\mathrm{b}-/ \mathrm{c} / \mathrm{b}+$ & $\mathrm{c}+/ \mathrm{c}+/ \mathrm{b}$ & $\mathrm{b}-/ \mathrm{c}+/ \mathrm{a}-$ & $\mathrm{c} / \mathrm{c} / \mathrm{b}+$ & $\mathrm{b} / \mathrm{b} / \mathrm{b}$ & $\mathrm{b} / \mathrm{b} / \mathrm{b}$ \\
\hline Telecommunications sector & $\mathrm{b} / \mathrm{b} / \mathrm{b}$ & $\mathrm{b}-/ \mathrm{b}-/ \mathrm{b}+$ & $\mathrm{b}-/ \mathrm{b}-/ \mathrm{b}+$ & $\mathrm{c}+/ \mathrm{c}+/ \mathrm{b}$ & & \\
\hline Material sector & $\mathrm{b}+/ \mathrm{b}-/ \mathrm{c}$ & $\mathrm{c}+/ \mathrm{c}+/ \mathrm{b}+$ & $\mathrm{b}-/ \mathrm{c}+/ \mathrm{b}+$ & $\mathrm{c}+/ \mathrm{c}+/ \mathrm{b}+$ & $\mathrm{c} / \mathrm{b} / \mathrm{b}$ & $\mathrm{c} / \mathrm{b}-/ \mathrm{b}$ \\
\hline
\end{tabular}

Own study based on: Analiza ESG spółek w Polsce, 2013, 2014, 2015, 2016, 2017, 2018.

In accordance with the ESG reports in Poland, the companies with the highest degree of transparency in Poland belong to the energy, financial, telecommunications and material sectors (which is illustrated in Table 5).

The analysis of non-financial data in the context of respect for the natural environment, stakeholders and corporate governance in years 2013-2018 indicates that the entities belonging to the energy sector show an upward trend in relation to the activities taking into account the ideas of CSR. The financial sector companies in the context of the previous period repeated the degree of the indicted practices at the average level whereas the entities from the material sector recorded a slight decrease in the area of respect for external stakeholders.

\section{Summary}

The existing voluntary disclosure of non-financial data had impact on a low level of published reports, to some extent consistent with the new scope of reporting, though. Consequently, for the majority of the companies listed on WSE, the need to compile the report compliant with Directive 2014/95/EU is a challenge.

In accordance with the SEG reports, the companies listed on the Warsaw Stock Exchange, belonging to the WIG20, WIG40, sWIG80 indices, are characterized by a low level of the reporting of ESG criteria.

The activities of the companies in the field of respect for silent stakeholders are mostly limited to the publication of the environmental policy, whereas in the field of social responsibility, to respecting provisions included in the Polish Labour Code. Only in the field of 
corporate governance the companies indicate a higher degree of reporting, which may result from the need to apply the Code of Good Practices ${ }^{10}$.

It is estimated that the obligation to publish non-financial data indicated, among others, in Directive 2014/95/EU may bring similar effects in subsequent years to the improvement in reporting the activities in the field of corporate governance (imposed by the Code of Good Practices).

\section{References}

1. Analiza ESG spótek w Polsce, GES Investment Services (2015). Warszawa. Available online https://seg.org.pl/pl/system/files/private-document-files/analiza_esg_wyniki_2015 robert_sroka.pdf, 02.04.2019.

2. Analiza ESG spółek w Polsce, Raportowanie danych niefinansowych ESG, a odpowiedzialne inwestowanie. Przewodnik dla spółek $i$ inwestorów (2014). Warszawa Available online https://seg.org.pl/sites/seg13.message-asp.com/files/seg_esg-2014_ srodki-pl_210x297_-_www-bez_pustych_stron.pdf, 02.04.2019.

3. Analiza ESG spótek w Polsce, Raportowanie niefinansowe, Wartość dla spótek i inwestorów (2016). Warszawa. Available online https://seg.org.pl/sites/seg13.messageasp.com/files/seg_esg-2016_www_5.pdf, 02.04.2019.

4. Analiza ESG spółek w Polsce, Raportowanie niefinansowe: Wymagania ustawy o rachunkowości a praktyka rynkowa (2017). Warszawa. Available online https://seg.org.pl/sites/seg13.message-asp.com/files/seg_esg-2017_210x297_www6_1.pdf, 28.03.2019.

5. Analiza ESG spótek w Polsce, Transparentność w obszarze ESG jako element przewagi konkurencyjnej spółki giełdowej (2013). Warszawa. Available online https://seg.org.pl/ sites/seg13.message-asp.com/files/esg_2013_wer-www.pdf, 02.04.2019.

6. Biznes odpowiedzialny $w$ Polsce $2019 r$. Available online http://grm-rpedit. newscyclecloud.com/assets/pdf/rp288681319.pdf, 18.04.2019.

7. Bylok, F. (2017). Podejście etyczne do pracowników w perspektywie społecznej odpowiedzialności przedsiebiorstw. In: E. Robak, A. Karczewska, M. Skiba (eds.), Zarzadzanie kapitałem ludzkim i społecznym wobec zmian we współczesnych organizacjach (pp. 45-54). Częstochowa: Wydawnictwo Wydziału Zarządzania Politechniki Częstochowskiej.

10 The more extensive aspect of Good Practices of listed companies was presented on the website: https://www.gpw.pl/pub/GPW/files/PDF/GPW_1015_17_DOBRE_PRAKTYKI_v2.pdf, 02.04.2019. 
8. Caroll, A.B. (2008). A History of Corporate Social Responsibility: Concepts and Practices. Business and Management, Business Policy and Strategy, History, January, 19-46, DOI: 10.1093/oxfordhb/9780199211593.003.0002.

9. Chluska, J. (2017). Wpływ obowiązku ujawnień modelu biznesu na system rachunkowości przedsiębiorstw. Kwartalnik Nauk o Przedsiębiorstwie, 11(44), 94-100.

10. Da Fonseca, L.M.C.M. (2015). ISO 14001:2015: An Improved Tool for Sustainability. Journal of Industrial Engineering and Management 8(1), 37-50, DOI: http://dx.doi.org/ 10.3926/jiem. 1298.

11. Deloitte, Raportowanie niefinansowe. Odpowiedzialność spoteczna biznesu i zrównoważony rozwój $w$ największych spótkach pod lupa. Available online https://www2.deloitte.com/pl/pl/pages/rady-nadzorcze/articles/biuletyn_rad_ nadzorczych_rada_nadzorcza/rada-nadzorcza-biuletyn-7-2017/raportowanieniefinansowe.html, 29.03.2019.

12. Directive 2014/95/EU of the European Parliament and of the Council of 22 October 2014 amending Directive 2013/34/EU as regards disclosure of non-financial and diversity information by certain large undertakings and groups, EU's Official Journal L 330 of 15.11.2014.

13. Dobre Praktyki spólek notowanych na GPW. Available online https://www.gpw.pl/ pub/GPW/files/PDF/GPW_1015_17_DOBRE_PRAKTYKI_v2.pdf, 02.04.2019.

14. Global Reporting Initiative (GRI). Available online http://www.mpit.gov.pl/media/21611/ G4RSPD_Zasadyraportowaniaiwskazniki.pdf, 25.03.2019.

15. ISO 26000. Available online http://www.mpit.gov.pl/media/42609/discovering_iso_ 26000.pdf, 22.03.2019.

16. Kopeć, K.D. (2014). Instrumentarium Społecznej Odpowiedzialności Biznesu. Zarzadzanie, Zeszyty Naukowe Politechniki Częstochowskiej, No. 14, 101-114.

17. Olejniczak, K. (2012). Społeczna odpowiedzialność a kreowanie przewagi konkurencyjnej przedsiębiorstw. Częstochowa: Sekcja Wydawnictw Wydziału Zarządzania Politechniki Częstochowskiej.

18. Porter, M.E., Kramer, M.R. (2006). Strategy and Society. The link between competitive advantage and corporate social responsibility. Harvard Business Review, December, 78-92.

19. Przychodzen, J., Gómez-Bezares, F., Przychodzen, W., Larreina, M. (2016). ESG Issues among Fund Managers-Factors and Motives. Sustainability 8/1078, 1-19, DOI: https://doi.org/10.3390/su8101078

20. Regulation of the Minister of Finance of 29 March 2018 on current and periodic information published by issuers of securities and conditions for recognizing as equivalent information required by the laws of a non-member state, Journal of Laws of 2018, item 757.

21. SIN. Available online https://standardy.org.pl/wppsndrd/wp-content/uploads/2017/10/ SIN.pdf, 25.03.2019. 
22. Social Accountability 8000. Available online http://www.mpit.gov.pl/media/15751/ pracodawcy_rp_norma_sa_8000.pdf, 22.03.2019.

23. Stowarzyszenie Emitentów Giełdowych. Available online https://seg.org.pl/pl, 02.04.2019.

24. The Act of 15 December 2016 amending the Act on Accounting, Journal of Laws of 2017, item 61.

25. The Act of 29 September of 1994 on Accounting, Journal of Laws 1994 No. 121, item 591.

26. The guidelines for reporting non-financial data are, among others, Account Ability 1000, London Institute of Social and Ethical Account Ability. Available online http://www.mpit.gov.pl/media/15752/Standard_AA1000_Zasady_Odpowiedzialnosci_200 8.pdf, 22.03.2019.

27. The Prince's Accounting for Sustainability (A4S). Available online https://www.accountingforsustainability.org/en/index.html, 23.03.2019.

28. Wielgórka, D., Chudzicki, M. (2018). Nowoczesne zarządzanie finansami przedsiębiorstwa $w$ erze przemystu 4.0. Częstochowa: Polskie Towarzystwo Ekonomiczne Oddział w Częstochowie. 